\title{
Management of Ductal Carcinoma In Situ Patients Receiving Postoperative Radiotherapy after Breast Conserving Surgery: Hacettepe Experience
}

\author{
Gokhan OZYIGIT, Sukran ULGER, Ferah YILDIZ, Murat GURKAYNAK \\ Hacettepe University Faculty of Medicine, Department of Radiation Oncology, Ankara, TURKEY
}

\begin{abstract}
We retrospectively evaluated our therapetic results in ductal carcinoma in situ (DCIS) patients treated with postoperative radiotherapy following breast-conserving surgery (BCS). Sixty-seven DCIS patients were treated with curative radiotherapy (RT) after BCS, in our department from December 1998 to January 2008. All patients have been treated with 6 MV photon energy on lineer accelerator machine. Radiotherapy treatment fields were opposed tangential to the whole breast. A total dose of median 50 Gy (48-50 Gy) was delivered in five fractions in a week. In twenty patients, boost dose to the tumour region was applied. Fifty patients received systemic hormonotherapy. Median follow-up time was 44 moths (range 12-122 months). Five-year OS, DFS and local control rates were found as 96\%, 97\% and $97 \%$, respectively. There was only one ipsilateral breast recurrence in our study (2\%). Two patients died due to other causes except disease (3\%). Grade III dermatitis was seen in only one patient (2\%), and there was no serious acute side effects in 41 patients (63\%). There was no late side effect in our patients. Sixty-two patients were alive without evidence of tumour recurrence, with their intact breast and with good cosmesis. Our survival rates and side effects were in consistent with literature, and RT is an effective option for DCIS patients following BCS.
\end{abstract}

Keywords: Ductal carcinoma In Situ, Radiotherapy, Breast conserving surgery

\section{ÖZET}

Duktal Karsinoma in Situ Olgularında Meme Koruyucu Cerrahi Sonrası Postoperatif Radyoterapi: Hacettepe Deneyimi

Bu retrospektif çalısmada meme koruyucu cerrahi (MKC) sonrası postoperatif radyoterapi uyguladığımız duktal karsinoma in situ (DKiS) olgularında tedavi sonuçlarımız retrospektif olarak değerlendirilmiştir. Anabilim Dalımız'da Aralık 1998 ile Ocak 2008 arasında 67 DKIS olgusuna MKC sonrası küratif radyoterapi uygulanmıștır. Tüm hastalar 6 MV fotonlarla lineer akseleratör cihazı ile tedavi edilmiştir. Radyoterapi iki paralel tanjansiyel alanla tüm memeye uygulanmıştır. Ortanca total doz 50 Gy (48-50 Gy) haftada 5 fraksiyonlar halinde verilmiştir. Yirmi hastada tümör yatağına ek doz uygulanmıştır. Elli olgu sistemik hormonal tedavi almıştır. Ortanca izlem süresi 44 aydır (12-122 ay). 5-yllık genel sağkalım, hastalıksız sağkalım ve lokal kontrol oranları sırası ile \%96, \%97 ve \%97 olarak saptanmıştır. Çalışmamızda sadece 1 ipsilateral nüks (\%2) gözlenmiştir. İki hastamız hastalık dışı nedenlerle kaybedilmiştir (\%3). Bir hastada (\%2) 3. derece dermatit saptanırken, 41 olguda (\%63) hiçbir ciddi akut yan etki saptanmamışırı. Olgularımızda ciddi geç yan etki gözlenmemiştir. Altmış iki olgu iyi kozmetik sonuçla hastalıksız hayattadır. Sağkalım ve yan etki sonuçlarımız literatür ile uyumlu olup, DKiS olgularında MKC sonrası radyoterapi etkin bir tedavi seçeneğidir.

Anahtar Kelimeler: Duktal karsinoma in Situ, Radyoterapi, Meme koruyucu cerrahi 


\section{INTRODUCTION}

Ductal carcinoma in situ (DCIS) is characterised by the development of cancerous cells in the milk ducts of the breast, and is a risk factor for invasive breast cancer development. Unlike invasive breast cancer, DCIS either has not yet invaded beyond its intraductal origin or may never invade beyond basal membrane. The diagnosis and management of DCIS is highly complex with many unanswered questions, including the fundamental natural history of untreated disease. Before mammographic screening, diagnosis of DCIS was rather incidental, as most cases were identified with a palpable mass, nipple discharge or Paget's disease of the nipple. With the advent of breast screening, the incidence of DCIS has increased from less than $1 \%$ to more than $10 \%$ of newly diagnosed breast cancers. ${ }^{1}$ The percentage of carcinoma in situ (including DCIS and lobular carcinoma in situ; LCIS) in screened population was reported to be in the range of 8.5 to $26 \% .^{2}$

There is a consensus that standard treatment of ductal carcinoma in situ (DCIS) is surgical removal of lesion with negative margins either by breast conserving surgery (BCS) or, if this is not possible, by simple mastectomy. However, controversy exists regarding the value of radiotherapy (RT) after BCS particularly for low-risk cases. ${ }^{3}$ Regarding the surgical management of DCIS, the preffered choice of many women and surgeons is BCS. However, the main risk of inadequately removing all the DCIS is either a recurrence of DCIS or the development of invasive breast cancer later even with a risk of progression to metastatic disease. Radiotherapy (RT) is applied to the whole breast after BCS to reduce the risk of developing recurrent disease (either DCIS or invasive breast cancer).$^{1-3}$ Three large multicenter randomized control trials (RCTs) have documented the benefits of RT after BCS with 50 to $60 \%$ reduction of the risk of local recurrence (LR). ${ }^{4}$ However, only less than $40 \%$ of patients treated with BCS received postoperative RT. ${ }^{5}$

Recently, several studies showed that RT after BCS is an effective option for local control with acceptable toxicity. However, the debate remains whether there is a low-risk group in which RT could be omitted safely. Several studies have used a decision model to examine DCIS treatment strategies, but

\begin{tabular}{|c|c|}
\hline & Number of Patients (\%) \\
\hline \multicolumn{2}{|l|}{ Age } \\
\hline$<40$ age & $5(8)$ \\
\hline $40-60$ age & $45(69)$ \\
\hline$>60$ age & $15(23)$ \\
\hline \multicolumn{2}{|l|}{ Menapausal status } \\
\hline Premenaposal & $28(43)$ \\
\hline Postmenaposal & $37(57)$ \\
\hline \multicolumn{2}{|c|}{ Symptoms at diagnosis } \\
\hline Mass & $26(40)$ \\
\hline Nipple discharge & $4(6)$ \\
\hline Pain & $3(5)$ \\
\hline
\end{tabular}

none modeled DCIS as a heterogeneous disease with different recurrence risks. Therefore, there is an emerging need to optimize local treatment strategies for the conservative management of DCIS. In this study, we retrospectively evaluated our DCIS patients treated with radiotherapy after BCS.

\section{PATIENTS AND METHOD}

Sixty-seven DCIS patients were treated with curative RT after BCS, in our department from December 1998 to January 2008. One patient who did not complete RT and one patient lost to follow-up excluded from the study. Data of remaining 65 DCIS patients analyzed retrospectively. Some characteristics of the patients are summarized in Table 1.

The median age was 53 years (range, 27-72 years). Twenty-eight patients were premenopausal (43\%), and others were postmenopausal period. Thirty-two patients were diagnosed with screening mammograpy $(49 \%)$. Breast conserving surgery was lumpectomy in 41 patients and excisional biopsy in 17 patients. Tumor characteristics including histological type, nuclear grade, width of the surgical margin, lesion size, receptor status, comedonecrosis presency are shown in Table 2.

All patients have been treated with $6 \mathrm{MV}$ photon energy on linear accelerator machine. Radiotherapy treatment fields were parallel opposed tangential to the whole breast. A median total dose of $50 \mathrm{~Gy}$ (Range, 48-50 Gy) was delivered in five fractions in a week. In 20 patients, boost dose to the tumor 


\begin{tabular}{|c|c|}
\hline & Number of Patients (\%) \\
\hline \multicolumn{2}{|l|}{ Tumor size } \\
\hline$<15 \mathrm{~mm}$ & $39(60)$ \\
\hline $16-40 \mathrm{~mm}$ & $24(37)$ \\
\hline$>40 \mathrm{~mm}$ & $2(3)$ \\
\hline \multicolumn{2}{|l|}{ Grade } \\
\hline Grade I & $13(20)$ \\
\hline Grade II & $16(25)$ \\
\hline Grade III & $21(32)$ \\
\hline Unknown & $15(23)$ \\
\hline \multicolumn{2}{|l|}{ C-erbB2 (IHC) } \\
\hline \multicolumn{2}{|l|}{$2+3(5)$} \\
\hline \multicolumn{2}{|l|}{$3+5(8)$} \\
\hline Negative & $29(44)$ \\
\hline Unknown & $28(43)$ \\
\hline \multicolumn{2}{|l|}{ Surgical margin } \\
\hline Negative & 64 (98.5) \\
\hline Close $(<1 \mathrm{~mm})$ & $1(1.5)$ \\
\hline \multicolumn{2}{|c|}{ Comedonecrosis } \\
\hline Present & $20(31)$ \\
\hline Absent & $32(49)$ \\
\hline Unknown & $13(20)$ \\
\hline \multicolumn{2}{|c|}{ Receptor status } \\
\hline $\mathrm{ER}+$ & $4(6)$ \\
\hline $\mathrm{PR}+$ & $4(6)$ \\
\hline $\mathrm{ER}+\mathrm{PR}+$ & $37(57)$ \\
\hline ER-PR- & $6(9)$ \\
\hline Unknown & $14(21.5)$ \\
\hline \multicolumn{2}{|c|}{$\begin{array}{l}\text { DCIS: Duktal Carsinoma In Situ } \\
\text { LCIS: Lobuler Carsinoma In Situ } \\
\text { ER: Estrogen Receptor } \\
\text { PR: Progesteron Receptor } \\
\text { DCISmic: Duktal Carsinoma In Situ Microinvazive }\end{array}$} \\
\hline
\end{tabular}

region was applied. Fifty patients received systemic hormonotherapy (Table 3).

All patients were examined after every five fractions, once in a week during RT. After the end of RT, patients were followed every 3 months for the first 2 years, every 6 months for the following 3 years and once a year after the end of the fifth year. Physical examination, complete blood count, chest $\mathrm{X}$-ray, serum biochemical analyses were performed in every follow-up visits. Mammography and breast ultrasonograpy were performed in every 6 months.

Treatment related complications were recorded as acute when they occured within the treatment peri-
Table 3. Systemic and hormonal therapy

\begin{tabular}{|lc|}
\hline & Number of Patients (\%) \\
\hline Hormonotherapy & \\
Present & $50(77)$ \\
Absent & $15(23)$ \\
Hormonotherapy & \\
Tamoxifen & $45(90)$ \\
Aromatase inhibitor & $5(10)$ \\
\hline
\end{tabular}

od or during 90 days after the end of the therapy and as late after then. Toxicity was graded according to Radiation Therapy Oncology Group (RTOG), Europen Organistaion for Research and Treatment of Cancer (EORTC) common toxicity criteria. $^{6}$

Statistical Analysis: All the data were collected in a database and were verified by a second independent person. According to the findings on last follow-up, patients were classified as "no evidence of disease" if labaratory and physical examination is normal, "alive with disease" if signs of relapse were detected and "exitus of other causes" if patient died from other causes except disease. "Diseasefree survival (DFS)" was defined as the time from surgery to the occurence of the first relapse either local or distant, and "overall survival (OS)" was defined as the time from surgery to death due to breast cancer or other causes.

Descriptive statistics were generated for all study variables, including mean and standart deviaton (SD) or median and range for continuous variables and relative frequencies and percentages for categorical variables. The distribution of the data was tested for normality by the Kolmogorov-Smirnov test. Two-tailed significance was defined as $\mathrm{p}<0.05$. Statistical analyses were performed using Statistical Package for Social Sciences (SPSS) for Windows version 15 (SPSS Inc, Chicago, Illinois, USA). DFS and OS rates were calculated using the Kaplan-Meier method. There was only one local recurrence in our study, and therefore we could not perform univariate or multivariate analysis for prognostic factor assessment. 


\begin{tabular}{|ll|}
\hline \multicolumn{2}{|c|}{ Table 4. Treatment-related acute side effects } \\
\hline & Number of Patients (\%) \\
\hline Dermatitis \\
Grade I \\
Grade II & $15(23)$ \\
Grade III & $8(12)$ \\
& $1(2)$ \\
\hline
\end{tabular}

\section{RESULTS}

Median follow-up time was 44 moths (range, 12122 months). Five-year OS, DFS and local control rates were found as $96 \%, 97 \%$ and $97 \%$, respectively. There was only one ipsilateral breast recurrence $(2 \%)$. Two patients died due to other causes except disease (3\%).

The patient with ipsilateral breast recurrence was 40 years old at the time of DCIS diagnosis. The tumor was $<15 \mathrm{~mm}$ in size, and all surgical margins were negative (with $4 \mathrm{~mm}$ tumour free margin). Whole breast RT (50 Gy) was applied after excisional biopsy. She received adjuvant Tamoxifen for five years after the RT due to estrogen and progesteron receptor positivity. Forty-three months after the diagnosis, breast cancer developed in the same breast but not in the primary tumor localization. Mastectomy was applied and she is alive without evidence of disease 12 months after the tumor recurrence.

Treatment-related acute side effects are listed in Table 4. Grade III dermatitis was seen in only one patient (2\%), and there were no acute side effects in 41 patients $(63 \%)$. There was no late side effect in our patients. Sixty-two patients were alive without evidence of tumour recurrence, with their intact organ and with good cosmesis.

\section{DISCUSSION}

Mastectomy and local excision with radiotherapy are both effective local therapeutic approaches in patients who have DCIS. Although outcomes between mastectomy and BCS or BCS+RT were not studied in a randomized fashion, several observational studies compared them. Current data demonstrate that long-term survival is similar with either approach. There is a higher local recurrence risk for DCIS with local excision and radiation therapy ( $12 \%$, half of whom have invasive cancer) than in patients who choose mastectomy (about $1 \%$ ). ${ }^{7}$ However mastectomy serves to reduce body image concerns, sexual function problems, and other psychosocial sequela after surgery.

Randomized clinical trials show that RT after local excision reduces the risk of both invasive and noninvasive local recurrence, compared with local excision alone..$^{910,11}$ Mature results of 4 multicentric randomised studies evaluating local and systemic treatment strategies for DCIS have been published. ${ }^{8}$ In 3 of these trials (NSABP-B-17, EORTC-10853, and SweDCIS trials) outcome of patients treated with BCS alone was compared to that of BCS followed by RT The EORTC trial found the 10-year local relapse-free rate was $85 \%$ with adjuvant radiotherapy compared to $74 \%$ without (HR $0.53, \log$ rank $\mathrm{p}<0.001$ ). The SweDCIS trial found the absolute risk reduction was $16 \%$ at 10 years, corresponding to a relative risk (RR) of 0.40 (95\% CI 0.30 to 0.54 ), for all ipsilateral breast events. The NSABP trial found the cumulative incidence of all ispilateral events at 12 years was $31.7 \%$ in the control group compared to $15.7 \%$ in the RT group (RR $0.43 ; 95 \%$ CI 0.32 to $0.58, \mathrm{p}<0.000005)$. The EORTC trial found the risk of invasive local recurrence was reduced by $42 \% \quad(p=0.0065)$. The NSABP trial found that invasive breast tumor recurrence was reduced from $16.8 \%$ to $7.7 \%$ ( $\mathrm{P}<$ $0.0001)$. The SweDCIS found ipsilateral invasive disease was reduced from $12.3 \%$ to $7.2 \% .^{9,10,11}$ In the United Kingdom, Australia, New Zealand DCIS Trial (UK/ANZ Trial), 1701 women who underwent excision of DCIS with clear margins were randomly assigned to RT (yes or no), and/or to tamoxifen versus placebo, using a two by two factorial design. The UKCCCR trial found the absolute risk of all ipsilateral events was reduced by $8.9 \%$ (from $13.7 \%$ in the control group to $4.8 \%$ in the RT group). The UKCCCR trial found that incidence of ipsilateral invasive disease was reduced from 5.3\% to $2.5 \% .^{12}$ In these four multicentric randomised trials that evaluated adjuvant radiotherapy in 3665 patients with DCIS submitted to BCT showed that adjuvant RT leads to a significant reduction $(60 \%)$ in the risk of a local (invasive and DCIS) in-breast recurrence. In spite of the reduced recurrence, the overall mortality and breast cancer mortality rates 
were not decreased for RT arm $(30 / 1711=1.75 \%)$ compared to observation arms $(33 / 1954=1.68 \%){ }^{13}$ However if we look at the results of the trials of radiotherapy following breast-conserving surgery for early invasive breast cancer, we will see effect of radiotherapy on breast cancer mortality. After 15 years follow-up, about one breast cancer death was avoided for every four local recur-rences avoided in the first 5 years. Theoretically, if about the same 1:4 ratio applied to DCIS, then radiotherapy might be expected to reduce breast cancer mortality by an absolute amount of about $1 \%$ or $2 \%$ by year 15 or $20 .{ }^{14}$ In consistent with literature, we demonstrated excellent local control rates with acceptable morbidity and good cosmesis with RT after BCS for DCIS patients. Five-year OS, DFS and local control rates were $96 \%, 97 \%$ and $97 \%$, respectively.

In the largest retrospective comparative series reported by Silverstein et al, thirty possible prognostic factors evaluated. ${ }^{15}$ There were 909 patients in this study. Of all, 326 patients underwent mastectomy, 237 excision plus RT, and 346 excision alone. The 10-year actuarial LR rates after BCS with or without RT were $20 \%$ and $28 \%$, respectively ( $\mathrm{p}=$ $0.06)$. Median times to LR were 57 and 25 months, respectively $(\mathrm{p}<0.01)$. In a multivariate analysis, the addition of RT after excision reduced the relative risk of LR by $55 \%(\mathrm{p}=0.0002)$. Nuclear grade, tumor size, margin width, comedo necrosis, and patient age were found as significant predictors of LR in this study. Combining these predictors they built the original Van Nuys Prognostic Index (VNPI). According to their treatment guidelines, patients with low (i.e. 4 to 6) USC/VNPI scores can be treated with excision alone, as no significant increase in LTC was observed with RT. Patients with intermediate (i.e. 7 to 9) scores showed an average of 10 to $15 \%$ LR-free survival benefit with the addition of RT. Although patients with high (i.e. 10 to 12) scores showed the greatest absolute benefit from RT, they experienced LR rates of almost $50 \%$ at 5 years. So mastectomy was recomended treatment strategy in these patients..$^{16}$ Although the VNPI (and USC/VNPI) was validated by the results of Silverstein's group , it should be tested in prospective randomized trials before being generally accepted. ${ }^{17}$ We could not analysed prognostic factors in our study, because there was only one recurrent disease in our study.
With the available information of randomized controlled trials, there was no evidence of excess deaths attributable to the addition of RT, either due to vascular disease, pulmonary toxicity, or second malignancies. Rate of death due to any cause was low in both arms of all trials and was similar between trials. However, if long-term toxicity due to RT does occur, a longer follow-up period may be required to show such an effect. In the early stage breast cancer studies, a significant excess of non-breast-cancer mortality in irradiated women (risk ratio 1.12, SE $0.04, p=0.001$ ) was shown. It was slight during the first 5 years, but continued after year 15 . The excess mortality was mainly from heart disease (risk ratio 1.27 , SE $0.07, \mathrm{p}=0.0001$ ) and lung cancer (rate ratio 1.78 , SE $0.22, \mathrm{p}=0.0004) .{ }^{18}$ However, RT side effects based on the result of early stage breast cancer patients could not accurately reflect that in DCIS patients receiving BCS with RT. The actual development of disease (such as vascular disease or malignancy) was not reported, only cause of death. As RT techniques continue to improve, such as the use of modern megavoltage regimen, small fraction sizes, and with computed tomography treatment planning exposure of nearby normal tissues is reduced also potentially decrease RT side effects. $4 \mathrm{We}$ observed no serious late effects due to the RT.

Solin et al. reported RT effect in DCIS in the largest multi-institutional series of 1003 mammographically detected DCIS patients treated with BCS and RT. At a median follow-up of 8.5 years there were only 100 LRs in the treated breast, yielding a 10year actuarial LR rate of $10 \% .{ }^{19}$ The experience of the Institute Curie over a 30-year period (1967 to 1996) was reported..$^{20}$ Among 601 DCIS patients, 343 were treated with wide excision plus RT. Overall 39 LRs $(8.8 \%)$ were observed during the study period: 9 recurrences (23\%) consisted of DCIS only, 27 (69\%) contained invasive cancer, and the histology of recurrence was unknown in $2(8 \%)$ patients. The 8 -year actuarial rate of LR was $11 \%$. In a recent meta-analysis of randomised trials the addition of RT to BCS resulted in a $60 \%$ risk reduction of both invasive and in situ recurrences. 9 In a multicentre retrospective study, an additional dose of $10 \mathrm{~Gy}$ to the tumour bed yielded a further $55 \%$ risk reduction compared to RT without boost. In the NSABP-B-24 trial, the addition of tamoxifen (TAM) to RT reduced ipsilateral (11.1\% vs. $7.7 \%)$ 
and contralateral ( $4.9 \%$ vs. $2.3 \%$ ) breast events significantly. In contrast, in the UKCCCR study, TAM produced no significant reduction in all breast events. Although, RT is shown to be effective on local tumor, BCS without postoperative RT has been widely used for the treatment of DCIS. The largest series of 256 patients was reported by Schwartz et al. ${ }^{21}$ At a median follow-up of 66.5 months (range: 12-247 months), there have been 71 second ipsilateral breast recurrences $(27.7 \%)$, including 26 invasive (37\%) and 45 DCIS only (63\%) recurrences. The 10-year actuarial local recurrence rate was $41 \%$ with the long-term projection of local recurrence being as high as $50 \%$ at 20 years. Blamey et al reported on the experience at the Nottingham City Hospital from 1988 through 2000, including 178 women who had been treated with wide local excision alone with circumferential margins clear to a depth of $10 \mathrm{~mm} .{ }^{22}$ At a median follow-up of 38 months there were 21 LRs (12\%): 12 of them were in situ (57\%) and 9 invasive (43\%). The actuarial rate of LR was $22 \%$ at 10 years. In 1998 , Boyages et al. published a meta-analysis of available retrospective studies of different local treatments for DCIS. ${ }^{23}$ Overall 1,148 patients treated with BCS alone and 1452 women treated with BCS plus RT were included. The meta-analysis suggested a LR rate of $22.5 \%$ for studies employing BCS alone, and $8.9 \%$ for BCS with RT. These figures indicated a clear and statistically significant difference between the recurrence rates of the two treatment options, despite the likelihood that patients undergoing BCS alone were more likely to have smaller, and possibly low-grade lesions with clear margins.

To date, there are insufficient prospective (and retrospective) data to support the hypothesis that excision alone may be the adequate local treatment strategy in patients with low-risk DCIS. No subgroups have been reliably identified that do not benefit from RT after BCS. Further prospective studies are warranted to identify subgroups of low-risk patients with DCIS for whom RT can be safely omitted. Until long-term results of ongoing studies on outcomes of patients treated with BCS alone (with or without TAM or aromatase inhibitors) are available, RT should be routinely recommended after BCS for all patients except those with contraindication. 9 Until the natural history and biology of DCIS and important therapeutic risk stratifications has been clearly defined, our study and currently available literature supports that RT is an effective and tolerable treatment strategy after BCS in the management of DCIS.

\section{REFERENCES}

1. Fietkau R. Ductal carcinoma in situ of the breast: Increasing importance of radiotherapy as a part of the therapy approach. Strahlenther Onkol 180:682-689, 2004.

2. Leonard GD, Swain SM. Ductal carcinoma in situ, complexities and challanges. I Natl Cancer Inst 96:906-920, 2004.

3. Adlard JW, Bundred NJ. Radiotherapy for ductal carcinoma in situ. Clin Oncol 18:179-184, 2006.

4. Wang SY, Kuntz K, Tuttle T, Kane R. Incorporating margin status information in treatment decisions for women with ductal carcinoma in situ: A decision analysis. Breast Cancer Res Treat DOI: 10.1007/s10549010-1166-7, 2010.

5. Sumner WE, Koniaris LG, Snell SE, et al. Results of 23,810 cases of ductal carcinoma-in-situ. Ann Surg Oncol 14:1638-1643, 2007.

6. Cox JD, Stetz J, Pajak TF. Toxicity criteria of the Radiation Therapy Oncology Group (RTOG) and the European Organization for Research and Treatment of Cancer (EORTC) Int $J$ Radiat Oncol Biol Phys 31:1341-6, 1995.

7. Virnig BA, Tuttle TM, Shamliyan T, Kane RL. Ductal carcinoma in situ of the breast: a systematic review of incidence, treatment, and outcomes. J Natl Cancer Inst 102:170-8. 2010.

8. Polgár C, Kahán Z, Orosz Z, et al. The Role of Radiotherapy in the Conservative Treatment of Ductal Carcinoma in Situ of the Breast. Pathol Oncol Res 14:179192, 2008.

9. Fisher ER, Dignam J, Tan-Chiu E, et al. Pathologic findings from the National Surgical Adjuvant Breast Project (NSABP) eight-year update of protocol B-17: Intraductal carcinoma. Cancer 86:429-438, 1999.

10. Bijker N, Meijnen P, Peterse JL, et al. Breast-conserving treatment with or without radiotherapy in ductal carcinoma in situ: Ten-year results of European Organisation for Research and Treatment of Cancer randomized phase III trial 10853-A study by the EORTC Breast Cancer Cooperative Group and EORTC Radiotherapy Group. J Clin Oncol 24:3381-3387, 2006.

11. Emdin SO, Granstrand B, Ringberg A, et al. SweDCIS: Radiotherapy after sector resection for ductal carcinoma in situ of the breast. Results of a randomised trial in a population offered mammography screening. Acta Oncol 45:536-543, 2006. 
12. Houghton J, George WD, Cuzick J, et al. Radiotherapy and tamoxifen in women with completely excised ductal carcinoma in situ of the breast in the UK, Australia, and New Zealand: randomised controlled trial. Lancet 362:95-102, 2003.

13. Viani GA, Stefano EJ, Afonso SL, et al. Breast-conserving surgery with or without radiotherapy in women with ductal carcinoma in situ: A meta-analysis of randomized trials. Radiat Oncol 2:28, 2007.

14. Early Breast Cancer Trialists' Collaborative Group (EBCTCG). Overview of the Randomized Trials of Radiotherapy in Ductal Carcinoma In Situ of the Breast. J Natl Cancer Inst Monogr 41:162-77, 2010.

15. Silverstein MJ. The university of Southern California/Van Nuys prognostic index. In: Silverstein MJ (ed) Ductal carcinoma in situ of the breast. Lippincott Williams \& Wilkins, Philadelphia, USA, pp 459-473, 2002.

16. Silverstein MJ. The Van Nuys/University of Southern California experience by treatment. In: Silverstein MJ (ed) Ductal carcinoma in situ of the breast. Lippincott Williams \& Wilkins, Philadelphia, USA, pp 337-342, 2002.

17. Silverstein MJ, Lagios MD, Craig PH, et al. A prognostic index for ductal carcinoma in situ of the breast. Cancer 77:2267-2274, 1996.

18. Clarke M, Collins R, Darby $\mathrm{S}$, et al. Effects of radiotherapy and of differences in the extent of surgery for early breast cancer on local recurrence and 15-year survival: an overview of the randomized trials. Lancet 366:2087-2106, 2005.

19. Solin LJ, Fourquet A, Vicini FA, et al. Long-term outcome after breast-conservation treatment with radiation for mammographically detected ductal carcinoma in situ of the breast. Cancer 103:1137-1146, 2005.

20. Forquet A, Sigal-Zafrani B, Clough KA. Breast-conserving surgery plus radiation therapy in ductal carcinoma in situ: The Institut Curie experience. In: Silverstein MJ (ed) Ductal carcinoma in situ of the breast. Lippincott Williams \& Wilkins, Philadelphia, USA, 367-372, 2002.
21. Schwartz GF. Treatment of subclinical ductal carcinoma in situ of the breast by local excision and surveillance: An updated personal experience. In: Silverstein MJ (ed) Ductal carcinoma in situ of the breast. Lippincott Williams \& Wilkins, Philadelphia, USA, 308321, 2002

22. Blamey RW, Macmillan RD, Rampaul RS, et al. Ductal carcinoma in situ: Experience at Nottingham City Hospital 1973 through 2000. In: Silverstein MJ (ed) Ductal carcinoma in situ of the breast. Lippincott Williams \& Wilkins, Philadelphia, USA, 322-328, 2002.

23. Boyages J, Delaney G, Taylor R. Predictors of local recurrence after treatment of ductal carcinoma in situ: A metaanalysis. Cancer 85:616-628, 1998.

\section{Correspondence}

Dr. Gökhan ÖZYiĞiT

Hacettepe Üniversitesi Tıp Fakültesi

Radyasyon Onkolojisi Anabilim Dalı

06100 Sinhiye, Ankara / TURKEY

Tel: (+90.312) 3052900

Fax: (+90.312) 3092914

e-mail: gozyigit@hacettepe.edu.tr 